\title{
ENFORCEMENT OF THE EUROPEAN UNION LAW BEFORE THE ALBANIAN CONSTITUTIONAL COURT AND THE HIGH COURT
}

\author{
Gentjan Skara* \\ Department of Law, "Bedër" University College, Albania \\ ORCID iD: https://orcid.org/0000-0003-1113-6600 \\ gskara@beder.edu.al
}

Bojana Hajdini

Department of Law, Epoka University, Albania

bhajdini@epoka.edu.al

\begin{abstract}
With the entry into force of the Interim Agreement in 2005 between the EU and Albania, Albanian judges had the obligation to partly apply several provisions of the agreement (the EU law) even in the pre-accession stage. This position was reinforced in 2009, with the ratification of the Stabilisation and Association Agreement, which laid down the obligation of the Albanian government to approximate its existing and future legislation in line with EU acquis and ensure proper implementation. Consequently, as of 2009, Albanian courts had to apply the EU law. The application of the EU law by Albanian courts entails the duty of judges with a twofold task: firstly, to construe their arguments in line with EU law or as close as possible, and secondly, to set aside the domestic law which is found to be incompatible with the EU law. This paper outlines some Albanian courts' decisions concerning applying the EU Law before accession to the European Union. The paper argues that Albanian judges have adopted a 'Euro-friendly' approach by referring to the EU Law and SAA agreement even in the pre-accession period. Nevertheless, looking closely at court decisions, the EU law is applied as a persuasive source of law to support the court's decision and not to explain the importance of relying on EU law or CJEU case law.
\end{abstract}

Keywords: Stabilisation and Association Agreement; Acquis; Constitutional Court; High Court; Enforcement

\section{INTRODUCTION}

In 2009, when the Stabilisation and Association Agreement (SAA) entered into force, judicial reform has been at the top priorities of the EU pre-accession. The European Commission's opinion on Albanian's application for the EU membership states that: "Administrative and judicial capacities remain overall limited and the country will need sustained efforts to strengthen them to be able to assume the obligations of the membership in the medium-term" (Commission 2010, 8). The judicial system in Albania 
is perceived as being highly corrupt, with very close links to politicians and organized crime (Erebara 2018). For this reason, in 2014, the Council has stressed that sustained implementation and fulfillment of reforms, inter alia, judicial reform, is necessary for the opening negotiations (Commission 2014), to properly address the judicial reform requirement to open EU negotiations, the Albanian Parliament appointed a Special Committee in November 2014, with a mandate to make proposals for the reform of the justice system in line with the EU conditionality. The Committee had three tasks: 1) to provide an in-depth analysis of the current state of organization and functioning of the judiciary to identify problems and needs; 2) to draft a strategic document for the objectives of the judicial, and 3) to propose amendments to the laws that will require changes to enable the implementation of the judicial reforms (Vendimi 96/2014). Assisted by the two main international experts the EU's 'Consolidation of the Justice System in Albania' project (EURALIUS) and the US Department of Justice's Overseas Prosecutorial Development, Assistance, and Training Program (OPDAT), the judicial legal package, after two opinions of Venice Commission (Venice Commission 2016a; 2016b), was approved unanimously, on 22 July 2016, by all 140 MPs in the Albanian Parliament (Kuvendii Republikës së Shqipërisë 2016). While the discussion of the judicial reform has been oriented toward reorganization of judicial structure and vetting process which is undergoing (Hoxha 2021, 159-162), a little has been written on the role of judicial harmonization in the pre-accession period and applicability of the EU law by Albanian national judges.

To the authors' best knowledge, two book chapters have been written so far on this subject. The book chapter written by Zymberi and Sali explored and analyzed the place of international law in the Albanian legal system and its application by Albanian courts, with a specific reference to the case-law of the Albanian Constitutional Law and the High Court. The chapter, also, considered the place and applicability of human rights, European law, and international criminal law (2015, 81-108). Another book chapter, written by Caka $(2014,28-36)$ provides a general overview of the position of international law in the Albanian legal system and analyses in more detail the application of the EU Law and the SAA by the Constitutional Court and the High Court in Albania focusing on 1) whether the Albanian courts acknowledge any special status to SAA compared to other international agreement; and 2) whether the EU Law is applied indirectly in the pre-accession stage. Both chapters provide a useful doctrinal approach concerning the applicability of the EU law by the highest court and analyze some cases where Albanian courts have relied on the EU law or the SAA. However, a more comprehensive analysis needs to be undertaken for two main reasons.

Firstly, the EU law is part of the Albanian legal system with the ratification of the SAA. Therefore, while Albanian main foreign policy is oriented toward European integration, it is important to stress out that national judges are obligated to interpret national law in the light of EU law and apply it properly. Consequently, national judges 
should be equipped with necessary continuous legal education on EU law since most of the EU judicial acquis is judge-made law (Ćapeta 2005).

Secondly, the experience of CEECs shows a 'Euro-friendly approach' even before accession (Albi 2007, 39-58; Kühn 2005a). For instance, the Czech Constitutional Court relied on the EU law as a tool for interpreting Czech legislation, before accession. The Constitutional Court's approach was based not on the approximation of technical rules, but rather on common European principles and values:

[...] The Constitutional Court [...] does not share the claimants' opinion that Community law is irrelevant to the Constitutional Court of the Czech Republic, i.e. a state outside the European Union when assessing constitutionality. Such a statement is unduly simplistic and schematic. One of the sources of primary Community law is the common principles of law which the Court of Justice derives from the constitutional traditions of the Member States of the European Union. [...] The Constitutional Court of the Czech Republic has repeatedly applied these common principles of law, which are not expressly set forth as written legal rules, but are applied in European legal culture (e.g. the principle of proportionality). [...] Primary Community law is thus not foreign to the Constitutional Court; rather, to a great extent - especially in the form of common European principles of law - it permeates the Court's decisional practice (cited in Bobek 2006, 287).

The same EU-friendly interpretation of national law in the light of the EU law has been followed as well by the Polish Constitutional Tribunal. In K 15/04 case, a group of members of the Sejm (the lower house of the Polish Parliament) argued that the 2004 Act on Elections to the European Parliament conflicted with the principle of the sovereignty of the Polish people (article 4 (1) of the Constitution), as well as with clauses granting the right to vote to Polish citizens only. The Polish Constitutional Tribunal held that: "whilst interpreting legislation in force, account should be taken of the constitutional principle of sympathetic predisposition towards the process of European integration and the cooperation between States". ${ }^{1}$ For these reasons, specific research focusing only on the EU law and its approach taken by Albanian highest courts need to be taken.

This article deals with the EU judicial harmonization in the pre-accession period and looks to the applicability of the EU law by Albanian national judges, with a specific reference to the Constitution Court and the High Court. Approximation of existing and future Albanian legislation with the EU acquis brings obligation of judicial harmonization, meaning that national courts should apply EU Law or take into account the interpretation of the European Court of Justice (ECJ) (today the Court of Justice of

\footnotetext{
1 Judgment of 31 May 2004, Participation of Foreigners in European Parliamentary Elections, K 15/04, para 10.
} 
the European Union) when applying provisions of domestic laws. In this context, this paper analyzes the enforcement of EU Law by the Albanian courts at the pre-accession stage. The study covers the period after the SAA entered into force (2009) and is based mainly on the jurisprudence of 1) the Albanian Constitutional Court and 2) the High Court. By analyzing some relevant cases from these courts, we shall illustrate the relationship and interaction between Albanian courts and EU legal obligations undertaken as a result of the European integration process.

The core methodology of this article is that of traditional legal doctrine, which is based on analyses and interpretation of the EU primary and secondary sources; jurisprudence of the ECJ; the SAA with Albania and Albanian legislation. Additionally, secondary sources such as books, journals, and website articles have been taken into consideration. Secondly, the authors have analyzed different case laws of the Albanian Constitutional Court and the High Court. Identifying cases in the Court of First Instance and the Court of Appeal has been difficult because decisions are not published online.

This article concludes that both the Albanian Constitutional Court and the High Court have followed a 'Euro-friendly approach' in the pre-accession period, however, the EU law is applied as a persuasive source of law to support the court's decision and not to explain the importance of the EU law. One of the main reasons that this article argues relates to the lack of EU legal education of judges and lawyers.

\section{THE INTERNATIONAL LAW AND THE ALBANIAN LEGAL ORDER}

The Albanian Constitution was adopted by a popular referendum on 22 November 1998 (Law 8417/1998) and last amended in 2020 (Law 115/2020), as a modern constitution adopts a friendly approach and contains several articles dedicated to the international law and its position of international law within the Albanian legal system. Article 5 stipulates that: "The Republic of Albania applies international law that is binding upon it". Article 116 (1), which provides sources of the Albanian legal system, lists ratified agreements second after the constitution followed by laws and by-laws. Moreover, it contains provisions that regulate the status of ratified agreements or norms produced by international/supranational organizations in the Albanian domestic order and delegates to international organizations state powers for specific issues based on international agreements.

Various academicians conceded that such an order, as stipulated in article 116, constitutes a formal hierarchy of the sources of law in the Albanian legislation for two main reasons (Omari and Anastasi 2010, 47; Zymberi and Sali 2015, 81-108). Firstly, article 4 of the Constitution establishes an undisputed position of the Constitution as the highest law in the territory of the Republic of Albania. Secondly, the international agreement ratified by the Albanian Parliament has a normative effect on the domestic 
legal system by their ratification (Bianku 2016, 16). Reading together articles 5 and 116, it becomes clear that Albania followed the monist approach of international law.

Article 116 of the Albanian constitution is complemented by article 122. Article 122 (1) clarifies that "any ratified international agreement constitutes part of the internal legal system after it is published in the Official Journal of the Republic of Albania". According to this provision, two conditions should be fulfilled for an international agreement to be part of the Albanian domestic order: firstly, any international agreement should be ratified by law. The main body vested with the power to ratify and denounce international agreements is the Assembly. Article 121 (1) enumerates certain types of international agreements that can be ratified or denounced only by the Assembly. ${ }^{2}$

Secondly, it should be published in the Official Journal of the Republic of Albania. Albanian Constitution does not foresee a special procedure for the publication of international agreements. Article 117 (3) of the Constitution, reads that "International agreements that are ratified by law are promulgated and published according to the procedures that are provided for laws". The ratified international agreements will enter into force as domestic legislation foresees. Article 84 (3) of the Constitution reads as follows: "The law shall enter into effect not earlier than 15 days since its publication in the Official Journal". Most importantly, international agreements should be translated into the Albanian language.

Albanian constitution provides the supremacy of ratified international agreements or norms issued by the international organizations over the domestic legal system. Article 122 (2), clearly stipulates that "an international agreement ratified by law has priority over the laws of the country that are incompatible with it". Article 122 (2), unequivocally, confirms that treaties ratified by law prevail over any laws not compatible with them. Such a position is maintained as well by article 131 (a) which stipulates the exclusivity of the Constitutional Court to declare void any domestic law that is not compatible with an international agreement.

Another issue regulated by article 122 (3) relates to the place of international organizations' norms within the Albanian domestic legal order. Article 122 (3) stipulates that: "The norms issued by an international organization have priority, in case of conflict, over the law of the country when the direct application of the norms issued by the organization is expressly contemplated in the agreement ratified by the Republic of Albania for participation therein". Comparing paragraphs 2 and 3, from a literal interpretation it can be argued that article 122 (3) stipulates that norms of the

\footnotetext{
${ }^{2}$ According to article 121 (1), these international agreements are as follow: 1) territory, peace, alliances, political and military issues; 2) human rights and freedoms, and obligations of citizens as provided in the Constitution; 3 ) the membership of the Republic of Albania in international organizations; 4) the assumption of financial obligations by the Republic of Albania; 5) the approval, amendment or repeal of laws. This list is not exhaustive since the Assembly pursuant to article 121 (2) still retains the discretionary power to ratify other international agreements.
} 
international organization have superiority even over the constitution, unlike ratified international agreements which have supremacy over the domestic legal system. At the same time, article 123 regulates the delegation of sovereignty to international organizations based on specific agreements. The law that ratifies an international agreement for delegation of sovereignty is approved by a majority of all members of the Assembly (The Constitution of Albania 1998 as amended, article 123/2). The Assembly may decide that the ratification of such an agreement be done through a referendum (article 123/3). Article 123 did not regulate to what extent such delegation of sovereignty can be permitted. In the case of compatibility of the Albanian Constitution with the Rome Statute for the International Criminal Court, the Albanian Constitutional Court ruled that the transfer of state power to the International Organization cannot undermine the country's constitutional identity. ${ }^{3}$ In other words, the transfer of sovereignty to the international organization is limited to "the extent that does not deform the constitutional and sovereign identity of the Albanian polity" (Korenica and Doli 2012, 109).

\section{THE STABILISATION AND ASSOCIATION AGREEMENT AND THE ALBANIAN LEGAL SYSTEM}

The Albanian Constitution remains silent on the status of the EU law in the Albanian legal system and lacks a specific clause on the applicability of EU law. The EU membership is regulated under a general clause on international organizations. The SAA signed between the EU and the EU Member States and Albania is considered an international agreement. Article 122 (3) eases the integration of Albania in the EU emphasizing indirectly that the norms of the organization (the EU acquis) have prevalence over the laws of the country in the case of conflict. In this context, article 122 (3) leaves the gate open for joining the EU without the constitutional amendments and at the same time, stipulate the primacy of EU law over the domestic legislation.

In 2014, an initiative to reform the judiciary system was initiated (Law 96/2014). During travaux preparatoires of the justice reform, the High-Level Expert Group proposed a draft amendment of the Constitution suggesting, inter alia, to include a subparagraph in article 122 (2) stipulating that "the EU law shall prevail over the domestic law of the Republic of Albania" and deleting the third paragraph which regulates the status of norms produced by the International Organisation (Venice Commission 2015). The rationale behind such a proposal was not to make subsequent changes to the Constitution after Albania acceded to the EU (ad hoc Parliamentary Committee 2015; PGDP 2016). However, in the end, it was decided not to reflect the

\footnotetext{
${ }^{3}$ Albanian Constitutional Court, Decision No. 186, 23.09.2002, V-186/02. In its reasoning, the Albanian Constitutional Court relied on the judgment of German Federal Constitutional Court on the Maastricht Treaty of 12 October 1993.
} 
supremacy of the EU law on the Albanian Constitution on the assumption that Albania is not yet an EU Member State.

The main legal basis for the relationship between the EU and Albania is Stabilisation and Association Agreement (SAA), which falls under the mixed agreement or associate agreement where "the Union may conclude with one or more third countries or international organization agreements establishing an association involving reciprocal rights and obligations, common action and special procedure" (TFEU, article 215). The SAA aims to create an association between the EU and each Western Balkan country with the final aim to bring closer to the standards applicable in the EU. As stipulated in article 1 (2) of SAA with Albania, the SAA cover different areas such as: strengthening democracy, the rule of law; providing an appropriate framework for political dialogue between the EU and Albania; developing economic cooperation; helping Albania to complete the transition into a functioning market economy promote harmonious economic relations and develop gradually a free trade area between the Community and Albania; and foster regional cooperation. Central to the SAA is the obligation to harmonize the countries' legislation with EU law where specified the areas of priority, which mainly lay in internal market and competition (Hajdini and Skara 2017).

Albania signed the SAA in 2006 and it entered into force in April 2009 after ratification by the EU Member states following their constitutional requirements. According to this Agreement, Albania is obligated to remodel its legal systems and adjust gradually compatible with the EU acquis (Hajdini and Skara 2017). In the absence of a specific reference in the Albanian Constitution, the applicability of the EU law, either directly or indirectly, needs to be established by the provisions governing the status of the international agreement. For an international agreement to be part of the Albanian legal system, it must, firstly, be ratified by the law ${ }^{4}$ and, secondly, published in the Official Journal. Only if these two conditions are met, can the ratified international agreement be directly applicable and have supreme authority over the domestic law. In the case Van Gend \& Loos (C-26/62), the European Court of Justice (ECJ) held that the European Economic Community "constitutes a new legal order of international law" and, since then, the EU law has evolved into a unique supranational legal order (Weiler 1991). Similar to the international agreements ratified by the Republic of Albania in May 2009, the SAA is directly applicable after entering into force (The Constitution of Albania 1998 as amended, article 122/1) and has supremacy over the domestic law (article $122 / 3)$.

\footnotetext{
${ }^{4}$ The Parliament is the main body responsible vested with the power for ratification of the international agreement. Article 121 (1) provides an exhaustive list of agreements that can be exclusively ratified or denounced by law from the Parliament. With regard to publication, no special procedure is laid down in the Constitution. Article 117 (3) provides that "international agreements that are ratified by law are promulgated and published according to the procedures that are provided for laws".

${ }^{5}$ Judgment of 5 February 1963, Van Genden Loos v Administratie der Belastingen, C-26/62, ECLI:EU:C:1963:1
} 
Another issue concerns the ability of individuals - either EU or Albanian citizens to be able to invoke the provisions of the SAA before national courts. The SAA was introduced as an instrument to bring Albania closer to the EU. Therefore, Albania must approximate its existing and future legislation and ensure its proper implementation. It is generally agreed by various authors that the European Agreement (EA) has served as a bedrock for the SAA (Blockmans and Lazowski 2006, 3), and the major difference between the EA and the SAA relates to the regional cooperation dimension and the stages of the approximation process (Marko and Wilhelm 2002, 170-174). Both the EA and SAA have identical provisions of fundamental freedoms except the time limit of implementation. Similar to the EA, the SAA contains the harmonization clause that imposes the obligation to interpret the national law in the light of the EU law (Mataija $2015,12)$.

So far, the ECJ has not dealt with a preliminary ruling on such interpretation. However, in the case of associated agreements concluded with the Central and Eastern European Countries (CEECS), the ECJ issued several judgments about the direct effects of the EA provisions. Therefore, the ECJ decisions on the direct effect of the European Agreement provision have an important role to clarify this issue. In the Demire/ case, where the ECJ decided on the scope and nature of the mixed agreement, the Court ruled that:

a provision in an agreement concluded by the community with nonmember countries must be regarded as being directly applicable when, regard being had to its wording and the purpose and nature of the agreement itself, the provision contains a clear and precise obligation which is not subject, in its implementation or effects, to the adoption of any subsequent measure. ${ }^{6}$

Proceeding from well-known established formula of direct effects in Demirel, in several cases such as Gloscuk, Kondova, ${ }_{1}^{8}$ Jany, ${ }_{1}^{9}$ Barkociand Malik, ${ }^{10}$ the ECJ has ruled that provisions of the EA on the right of the establishment have direct effect, and the nationals of the respective countries can rely on those provisions in the EU Member States courts even in the period of pre-accession. In all four cases, the ECJ found that

\footnotetext{
${ }^{6}$ Judgment of 30 September 1987, Meryem Demire/ v Stadt Schwäbisch Gmünd., C-12/86, ECLI:EU:C:1987:400, para 14. This approach was reaffirmed in a subsequent Judgment of 4 May 1999, Sema Sürül v Bundesanstalt für Arbeit, C262/96, ECLI:EU:C:1999:228, para 60.

7 Judgment of 27 September 2001, The Queen and Secretary of State for the Home Department ex parte $v$ Wieslaw Gloszczuk et Elzbieta Gloszczuk, C-63/99, ECLI:EU:C:2001:488.

8 Judgment of 27 September 2001, The Queen and Secretary of State for the Home Department ex parte $v$ Eleanora Ivanova Kondova, C-235/99, ECLI:EU:C:2001:489.

9 Judgment of 20 November 2001, Aldona Malgorzata Jany and Others v Staatssecretaris van Justitie, C-268/99, ECLI:EU:C:2001:616.

10 Judgment of 27 September 2001, The Queen and Secretary of State for the Home Department ex parte $v$ Julius Barkoci and Marcel Malik, C-257/99, ECLI:EU:C:2001:491.
} 
the establishment provisions, such as Article 44 (3) of the Polish Association Agreement in the Gloszczuk case, had a direct effect. The Court's justification was as follows:

32. Article 44 (3) lays down, in clear, precise, and unconditional terms, a prohibition preventing the Member States from discriminating, on grounds of their nationality, against, inter alia, Polish nationals wishing to pursue, within the territory of those States, economic activities as self-employed persons or to set up and manage undertakings there which they would effectively control.

33. This rule of equal treatment lays down a precise obligation to produce a specific result and, by its nature, can be relied on by an individual before a national court to request it to set aside the discriminatory provisions of a Member State's legislation making the establishment of a Polish national subject to a condition which is not imposed on that Member State's nationals, without any further implementing measures being required for that purpose. ${ }^{11}$

These decisions indicate that the EA provisions are capable of entailing direct effects once firstly, they fulfill the criteria established in Demirel and Sürül cases, and secondly, the European Agreement is ratified following the requirement of the CEECs constitutions. Thus, EA provisions having direct effects did not require the adoption of implementing provisions. In the same vein, the SAA provisions are capable of having direct effects. The following section analyses the judicial harmonization of Albanian judges and shows the approach taken by Albanian judges to apply EU law.

\section{THE EUROPEAN COURT'S CASE-LAW CONCERNING ALBANIA}

\section{Application of the EU Law by the Constitutional Court in Pre-Accession Period}

During the pre-accession period, the major challenge faced by the CEECs national courts was whether legislative harmonization 'should be accompanied by judicial harmonization' (Albi 2005, 52). According to Albi, judicial harmonization means that 'the national courts should apply the interpretation of the European Court of Justice and take account of the EU legislation when applying the provisions of domestic laws or the provisions of Europe Agreements' (Albi 2005, 52). The CEECs pre-accession experience has shown a 'Euro-friendly approach' of the national courts in the interpretation and application of the domestic legal system (Albi 2005, 52-56; Kühn 2005b; Bobek 2006; Goldammer and Matulionyté 2007. Likewise, since April 2009 when the SAA entered into

\footnotetext{
11 Judgment of 27 September 2001, The Queen v Secretary of State for the Home Department, ex parte Wieslaw Gloszczuk and Elzbieta Gloszczuk. C-63/99, ECLI:EU:C:2001:488, paras. 32-33.
} 
force, the Constitutional Court has adopted a 'Euro-friendly approach' to interpret the national law in the light of the EU secondary law or SAA provisions.

According to the direct applicability of the SAA as an international agreement, in the Decision 24/2009, the Constitutional Court invoked directly the SAA standstill clause provision (article 33) and other restrictive quantitative restrictions on import or measures having equivalent effects (article 42) against a decision of the Council of Ministers in terms of quality standards of diesel oils. ${ }^{12}$ The Council of Ministers imposed a ban on the import of certain products and at the same time considered domesticproduced diesel oils as more favorable compared to imported products (DCM 52/2009). In assessing whether the restriction of economic freedom imposed by the Council of Ministers' Decision complies with the SAA provisions, the Constitutional Court referred to article 33 (2) SAA which explicitly stipulated that: "no new quantitative restrictions on imports or exports or measure having equivalent effect shall be introduced, nor shall those existing be made more restrictive, in trade between the Community and Albania".

Furthermore, the Constitutional Court rejected the claimants' argument according to which bans were justified on article 42 'restrictions authorized'. On the other side, the claimants failed to prove that such a measure does not constitute a means of arbitrary discrimination or a disguised restriction on trade. While the Constitutional Court adopted a 'Euro-friendly approach', it did not address the basic question about the reasons why the SAA provisions must be applied. Furthermore, the Constitutional Court neither looked at the substance of articles 34 and 36 of the Treaty on the Functioning of the European Union (TFEU) for a consistent interpretation nor elaborated further the notion of quantitative restrictions or measures having an equivalent effect with the quantitative restriction. It was the first time the Constitutional Court applied directly to the SAA provisions and rejected the national law.

The Constitutional Court has also considered the secondary sources of the EU law to make a consistent interpretation of the national law. In Decision 3/2010, concerning the constitutionality of the law 'On statutory audit, the organization of the profession of the statutory auditors and chartered accountants', the Constitutional Court took into consideration the Directive 2006/43/EC 'On statutory audits of annual accounts and consolidated accounts' to justify the rejection of the claim that the national law was unconstitutional. ${ }^{13}$ The claimant - Professional Association of Economists (Organizata Profesionale e Ekonomistëve) - claimed that Law 10091/2009 'On legal auditing and the organization of the profession of the statutory auditors and chartered accountants' was in violation with the EU law, since it established a monopolistic situation by creating an Institute of Authorised Auditors (Institutii Ekspertëve Kontabëltë Autorizuar) which interfered in the exercise of the auditors' profession and discriminated foreign auditors.

\footnotetext{
12 Judgment of 24 July 2009, Albanian Constitutional Court, V-24/09, [2009] OJ 119.

13 Judgment of 5 February 2010, Albanian Constitutional Court, V-3/10, [2010] OJ 17.
} 
That being said, Law 10091/2009 must be declared unconstitutional. The Constitutional Court referred to the Directive 2006/43/EC which regulates the profession of auditing. The Constitutional Court found no signs of violation of professional independence by the state supervision of auditors because, inter alia, such supervision complies with article 32 of the Directive 2006/43/EC.

In Decision 56/2016, the Constitutional Court assessed whether the restriction of ownership foreseen in Article 62 (3) of Law 97/2013 reading as follow: "No physical or juridical person, local/national or foreign, may have more than 40 percent of the total capital of a joint-stock company, which possesses a national license of audio broadcasting or a national license of audio-visual broadcasting", complies with the Directive 2010/13/EU. In its reasoning, the Constitutional Court found that the national measures, specifically Article 62 (3), fail to comply with the Albanian obligation to harmonize its domestic law since the Directive 2010/13/EU does not require any restriction of ownership from the companies operating in the media. ${ }^{14}$ In both these decisions, the Constitutional Court did not provide any clarification 1) why relied on the EU law secondary sources to support its judgment, and 2) the impact of the EU law secondary sources on the Albanian legal system.

While the application of the EU law in the pre-accession phase depends on the judges' 'European convictions', the competition law has been considered as a privileged area where the EU law including the Commission's soft laws should be applied even in terms of pre-accession. Experience from CEECs countries and other Western Balkan countries (Bosnia and Herzegovina; North Macedonia; Serbia and Croatia) reveal case practice assessing restrictive agreement in the light of EU law or Commissions soft laws (Kühn 2005b; Meškić and Samardžić 2014, 69-70; Goldner Lang and Mataija 2014, 95 96; Georgievski et al. 2014, 122; Vukadinović et al. 2014, 150). In addition to the obligation stemming from the approximation clause (article 70 SAA), article 71 (2) SAA requires an interpretation of the national competition law in the light of the criteria arising from the application of the EU competition rules applicable - in particular from articles 101, 102, 106 and 107 TFEU and the interpretative instruments adopted by the Community institutions - soft laws of the Commission and the ECJ decisions. Hence, article 71 SAA has direct effects, and the Albanian courts are obligated to rely upon the EU competition law and interpretative instruments adopted by the Community institutions to interpret the national competition law. This interpretation has been confirmed by the Constitutional Court in the Decision V-14/14 where:

31. The Court notes that under the Stabilisation and Association Agreement, practices contrary to article 71 (competition and other economic provisions) are assessed based on criteria arising from the application of the competition rules applicable in the Community, in

\footnotetext{
${ }^{14}$ Judgment of 27 July 2016, Albanian Constitutional Court, V-56/16, [2016] OJ 152, paras 52-53.
} 
particular articles 8182,86 and 87 of the Treaty establishing the European Community, and interpretative instruments used by Community institutions. In these circumstances, as in previous judgments, the Court finds it appropriate to refer to the jurisprudence of the European Court of Justice, regarding the application of competition rules in compliance with this Agreement. ${ }^{15}$

Even in this case, the Constitutional Court failed to clarify the recourse on the SAA provision even though article 71 (2) explicitly refers to the interpretation of the national competition law in light of the EU competition law. Moreover, the Constitutional Court language - 'in these circumstances, as in previous judgment, the Court finds it appropriate' - casts doubts on whether the reference to the ECJ decision stems from article 71 (2) SAA or because of the harmonization clause stipulated in article 70 of SAA.

\section{Application of the EU Law by the High Court in Pre-Accession Period}

Law 98/2016 regulates the judicial power in Albania and was a result of judiciary reform in 2016. As stipulated in the Albanian Constitution and confirmed by article 3 (1) of Law 98/2016, the judicial power is exercised by a three-level court: the High Court; the Court of Appeal, and the Court of First Instance (Law 98/2016, article 3/1). For this study, we will limit ourselves only to the practice of the High Court. The High Court operates in three Chambers according to jurisdiction subject matter: the Civil Chamber, the Criminal Chamber, and the Administrative Chamber (Law 98/2016, article 31). Also, the High Court adjudicates in Joint Chambers (the civil, criminal, or administrative cases) by the decision of either one of its adjudication panels or the Chairperson of the High Court. According to article 32 (2) of Law 98/2916, the Joint Chambers adjudicate cases where: firstly, the same legal question was not interpreted uniformly by different chambers of the High Court; or secondly, where there is a risk of a non-uniform interpretation among different chambers of the High Court. The subsequent section analyses the practice of the High Court in applying EU Law.

The tendency to adopt a 'Euro-friendly approach' has also been followed by the High Court. Interestingly enough, in the first case, the High Court referred to Regulation $1182 / 71$ that determines the rules applicable to periods, dates, and time, to interpret some provisions of the Civil Code. Regulation 1182/71 was cited just as an international agreement without clarifying the reasons why it was considered relevant. ${ }^{16}$

\footnotetext{
15 Judgment of 21 March 2014, Albanian Constitutional Court, V-14/14, [2014] OJ 50.

16 Judgment of 27 March 2012, High Court, No 2, [2012] OJ 106. In a later unified administrative decision, the High Court reconfirmed, again, interpretation of the domestic provision in the light of the Regulation (EEC, Euratom) 1182/71 of the Council of 3 June 1971. Judgment of 29 February 2016, High Court, No 1, [2016] OJ 93, para 40.
} 
In another case, the High Court had to rule on the issue of whether it is under the Albanian courts' jurisdiction to review an application for the interim injunction when the parties have an agreement for another jurisdiction. The High Court cited Regulation $44 / 2001$ on 'jurisdiction and the recognition and enforcement of judgments in civil and commercial matters' arguing that "despite the fact that our country is not yet a member of the European Union with all the rights pertaining thereto, directives (regulation) adopted by them are guiding for our legal practice. ${ }^{17}$ Only a few days later, the High Court acknowledged the importance of the process of approximation of the existing Albanian legislation with the acquis. The High Court stated that:

Our country should strive to ensure that its existing and future legislation converge move gradually towards alignment with the acquis communauitaire. Albania shall ensure that the existing and future legislation be applied and imposed properly (article 70 of Law No. 9590, 27.07.2006 'On the Ratification of the Stabilisation and Association Agreement with Albania and European Communities and its Member States'). ${ }^{18}$

There has been a relatively increasing attitude to embrace the 'Euro-friendly approach'. The High Court has relied on the ECJ cases to interpret the national legislation. In the Judgment of 27 April 2015, a case concerning sexual relations with the minors as stipulated by article 100 of Albanian Criminal Code, the Joint Chamber of the High Court referred to Pupino case ${ }^{19}$ which "argued the obligation of the Member States to interpret their procedural criminal law in the light of the EU law and the protection of vulnerable victims, such as minors, with respect to the life and privacy of the minor, giving their testimony in accordance with the measures taken to protect them to a certain level" ${ }^{20}$ In its decision, the Joint Chamber of the High Court failed to explain the reasons for relying on the $\mathrm{ECJ}$ cases and their impact on candidate countries.

In the Judgment of 29 February 2016, concerning the partial annulment of an administrative act of the General Director of State Police, the Joint Chamber of the High Court referred to the European Convention on the Calculation of Time-Limits, adopted on 16 May 1972 that is not ratified by Albania and the EC Regulation 1182/71 which determines the rules applicable to periods, dates and time limits. The Joint Chamber of the High Court emphasized that according to article 3 (1) of the Regulation 1182/71 "where a period, expressed in days, weeks, months or years is to be calculated from the moment at which an event occurs or an action takes place, the day during which that event occurs or that action takes place shall not be considered as falling within the

\footnotetext{
17 Judgment of 11 January 2011, High Court, No 22, [2011] OJ Special Edition, 125.

18 Judgment of 17 January 2011, High Court, No 1, [2011] OJ 88-e.

19 Judgment of 16 June 2005, Pupino, C-105/03, ECLI:EU:C:2005:386.

20 Judgment of 27 April 2015, Judicial Chamber of the High Court, No 1, [2015] OJ 142, para 48.
} 
period in question". While the Joint Chamber explained that Albania has not ratified this convention and does not have legal effects due to lack of ratification (Constitution of Albania, article 122/1), the impact of EC Regulation on Albania's legal system was not elaborated. The Joint Chamber just cited and stipulated the object of this regulation as a persuasive source to support the decision. ${ }^{21}$

In another case, the Judgment of 23 March 2016 concerning the dissolution of marriage and the consequences upon the children, the Civil Chamber of the High Court argued that the recourse of the plaintiff is contrary to the EU Law. In elaborating this position, the Civil Chamber of the High Court firstly provided a general overview of the SAA signed between EU and EU MS on one hand and Albania on the other hand. According to articles 6 and 70 of the SAA, Albania is obligated to ensure existing and future legislation in compliance with the EU acquis. Secondly, the Civil Chamber of the High Court, after explaining the legal nature of regulation, emphasized that "despite the fact that the Republic of Albania has not yet become a full member of the European Union, the regulations adopted by them are a guide in our legal practice". Finally, the Court concluded that:

Currently, in the pre-accession phase, the Republic of Albania has no obligation for the direct application of the EU normative system. National courts may refer to Community law in cases of legal omissions or collisions (praeter legem), but in no case should this interpretation be contrary to the provisions of national domestic law (contra legem). ${ }^{22}$

The 'Euro-friendly approach' of the High Court was further elaborated in the Judgment of 2 July 2020 and Judgment of 8 July 2020. Both these cases concerned the dissolution of the marriage. The Civil Chamber of the High Court interpreted the amendment of article 38 of the Code of Civil Procedure based on the obligation stemming from Regulation (EU) 1215/2012 'on jurisdiction and the recognition and enforcement of judgments in civil and commercial matters'. The Court argued that this obligation is foreseen in Art 70 of the SAA which reads as follow:

1. The Parties recognize the importance of the approximation of Albania's existing legislation to that of the Community and its effective implementation. Albania shall endeavor to ensure that its existing laws and future legislation shall be gradually made compatible with the Community acquis. Albania shall ensure that existing and future legislation shall be properly implemented and enforced. ${ }^{23}$

\footnotetext{
21 Judgment of 29 February 2016, Judicial Chamber of the High Court, No 1, [2016] OJ 93, para 40.

22 Judgment of 23 March 2016, the Civil Chamber of the High Court, N 94, [2016]. The same argumentation was maintained as well in the judgment of 29 June 2017, the Civil Chamber of the High Court, N 81, [2017].

${ }^{23}$ Stabilisation and Association Agreement between the European Communities and their Member States, of the one part, and the Republic of Albania, of the other part - Protocols - Declarations [2009] OJ L 107.
} 
In the Court's opinion, based on this provision, the Albanian government has taken the commitment to gradually approximate Albanian legislation with EU acquis as a precondition before accession. Moreover, in the Court view:

Article 70 of the SAA is an instrument through which the EU Law is internalized, absorbed, and becomes part of the Albanian legal order. The obligation enshrined in article 70 of the SAA, in the first place establishes the positive obligation for the legislature to have the law of the European Union as a basic standard during the law-making process. Secondly, article 70 imposes an obligation on judicial bodies, in the course of their daily work of resolving disputes, to the extent possible, to apply and interpret the law in the spirit of Community law. ${ }^{24}$

For the first time since 2009 when SAA was ratified, the High Court of Albania articulated clearly the 'Euro-friendly approach' even in the pre-accession phase based on article 70 of the SAA. In these decisions, the High Court highlighted the obligation of the judiciary to apply and interpret Albanian Law in the spirit of the EU Law. It remains to be seen how the Court of First Instance and the Court of Appeal will address the issue of enforceability on EU Law.

\section{CONCLUSION}

Since 2009, when the SAA entered into force, judicial reform has been at the top priorities of the EU pre-accession. The judicial system in Albania is perceived as being highly corrupt, with very close links to politicians and organized crime (Erebara 2018). While since 2016 the judiciary system in Albania has been faced with a huge reform, this paper analyzed the role of judicial harmonization in the pre-accession period and the applicability of the EU law by Albanian national judges.

The paper showed that likewise the CEECs countries, even the Albanian Constitutional and the High Court followed a Euro-friendly approach even before accession. In several case decisions, both courts acknowledged the importance of the approximation process as Albania is a candidate country and referred to the EU's primary and secondary sources. Nevertheless, looking closely at court decisions, the EU law is applied as a persuasive source of law to support the court's decision and not to explain the importance of relying on EU law or ECJ case law. In some decisions, the EU law is cited as an international agreement without going into further details on the reasons why it has been considered and its impact on the national legal system. Only recently in 2020, the Albanian High Court explained the relevance of article 70 of the

\footnotetext{
24 Judgment of 2 July 2020, the Civil Chamber of the High Court, N 213, [2020], para 16.1 and Judgment of 8 July 2020, the Civil Chamber of the High Court, N 213, [2020], para 15.1
} 
SAA 'approximation clause' and argued the need for the judiciary to interpret domestic existing and future legislation in line with the EU acquis.

One of the main reasons for the very limited EU judicial harmonization in Albania relates to the lack of proper EU legal education of judges and lawyers. According to Law 96/2016, candidates for judges have to attend for three years the Albanian School of Magistrates. Only after completing the final exam and vetting process (Law 96/2016, article 35), the judges are eligible to be appointed by respective councils. In the School of Magistrates, the course 'The EU Law' is included in curricula as obligatory in the first year. The course is given in two semesters with 36 hours in total and the SAA with Albania is given only 2 hours (School of Magistrates 2021). Whereas concerning the continuous education of the judges, the Albanian School of Magistrates organizes various training on different topics of EU where judges have discretion whether to attend or not.

As Albania is waiting to open accession negotiations and under the obligation to approximate its legislation with the EU acquis, the School of Magistrates should pay more attention to increase the hours for EU law course for two main reasons. Firstly, judges will be able to understand properly the EU Legal system and its case law because as stipulated in the case Van Gend en Loos, the ECJ held that the EEC "constitutes a new legal order of international law" and most of the EU judicial acquis is judge-made law (Ćapeta 2005). Secondly, an emphasis should be given to the impact of the SAA in Albania and the obligation for EU judicial harmonization. Moreover, considering the importance of EU Law and 'its distinctive nature', training for continuous education should be mandatory and not at the discretion of the judges to select it. In a conclusion, while the approach so far has been positive by the Albanian highest court to follow a 'Euro-friendly approach' referring to the EU law in the pre-accession stage, however, more awareness should be the importance of the EU judicial harmonization. 


\section{REFERENCES}

1. Ad Hoc Parliamentary Committee. 2015. "Explanatory Note on the Constitutional Amendments." Accessed 23 July 2021. https://euralius.eu/images/JusticeReform/Explanatory-Note-on-the-Constitutional-Amendments.pdf. point 1

2. Albanian Constitution Court, Decision nr. 186, date 23.09.2002, V-186/02

3. Albanian Chamber of Advocacy. 2021. "Continuous Legal Education." Accessed 1 July 2021. http://www.dhka.org.al/index.php/trajnimet/programi-i-arsimit-ligjorvazhdues

4. Albi, Anneli. 2005. EU Enlargement and the Constitutions of Central and Eastern Europe. Cambridge: Cambridge University Press.

5. Albi, Anneli. 2007. "Selected EU judgments by CEE Constitutional Courts: Lessons on How (not) to Amend Constitutions" CYELP3:39-58.

6. Bianku, Ledi. 2016. "Albania's long path toward European human rights standards" in The Impact of the ECHR on Democratic Change in Central and Eastern Europe, edited by lulia Motoc and InetaZiemele, 13-38. Cambridge: Cambridge University Press

7. Blockmans, Steven., and Lazowski, Adam. 2006. "The European Union and its neighbors: questioning identity and relationships" in The European Union and its neighbors: a legal appraisal of the EU's policies of stabilization, partnership and integration, edited by Steven Blockmans and Adam Lazowski, 3-18. The Hague: T.M.C. Asser Press

8. Bobek, Michal. 2006. "A New Legal Order, or a non-existent one? Some (Early) Experiences in the Application of EU Law in Central Europe" Croatian Yearbook of European Law and Policy 2:265-298.

9. Caka, Fjoralba. 2014. "The Application of the International and European Union Law by National Courts in Albania" in European Union Law Application by the National Courts of the EU Membership Aspirant Countries from South-East Europe, edited by Goran Koevski, et al., 27-59. Skopje: Centre for SEELS

10. Ćapeta, Tamara. 2005. "Courts, Legal Culture and EU Enlargement" Croatian Yearbook of European Law and Policy 1:23-57

11. Commission. 2010. 'Commission Opinion on Albania's Application for Membership of the European Union' (Communication) COM(2010) 680

12. Commission. 2014. 'On Albania's Progress in the Fight Against Corruption and Organised Crime and the Judicial Reform' (Report from the Commission to the

13. Council and the European Parliament) COM (2014) 331 final

14. Council Regulation (EC) No 44/2001 of 22 December 2000 on jurisdiction and the recognition and enforcement of judgments in civil and commercial matters [2001] OJ L 12/1 
15. Decision of Council of Minister 52/2009, 'On the quality of diesel produced from the refining of crude oil extracted in the territory of the Republic of Albania and marketed for road vehicles and generators' [2009] OJ 5

16. Directive 2010/13/EU of the European Parliament and of the Council of 10 March 2010 on the Coordination of Certain Provisions laid down by Law, Regulation or Administrative Action in the Member States Concerning the Provision of Audiovisual Media Services [2010] OJ L95/1

17. Erebara, Gjergj. 2018. "Albanian High Court Judge Sacked over Crime Connections." Accessed 4 June 2021. https://balkaninsight.com/2018/07/30/albania-high-court-judge-vetted-overconnection-with-organized-crime-07-30-2018/

18. Georgievski, Sašo., et al. "Application of the Law of the European Union in the Republic of Macedonia" in European Union Law Application by the National Courts of the EU Membership Aspirant Countries from South - East Europe, edited by Goran Koevski, et al., 99-130. Skopje: Centre for SEELS 2014.

19. Goldammer, Yvonne., and Matulionyté, Elzé. 2007. "Towards an Improved Application of European Union Law in Lithuania: The Examples of Competition Law and Intellectual Property Law" Croatian Yearbook of European Law and Policy 3:307-330.

20. Hajdini, Bojana., and Skara, Gentjan. 2017. "Lost in Implementation: EU Law Application in Albanian Legal System" Journal of Legal Studies 19: 43-64.

21. Hoxha, Andi. 2021. "The EU Rule of Law Initiative Towards the Western Balkans" Hague Journal on the Rule of Law 13: 143-172

22. Judgment of 29 February 2016, High Court, No 1, [2016] OJ 93

23. Judgment of 5 February 1963, NV Algemene Transport- enExpeditieOnderneming van Gend\& Loos v Netherlands Inland Revenue Administration, C-26/62, ECLI:EU:C:1963:1

24. Judgment of 11 January 2011, High Court, No 22, [2011] OJ Special Edition

25. Judgment of 16 June 2005, Pupino, C-105/03, ECLI:EU:C:2005:386

26. Judgment of 17 January 2011, High Court, No 1, [2011] OJ 88-e

27. Judgment of 2 July 2020, the Civil Chamber of the High Court, N 213, [2020]

28. Judgment of 2 July 2020, the Civil Chamber of the High Court, N 213, [2020], para 16.1 and Judgment of 8 July 2020, the Civil Chamber of the High Court, N 213, [2020]

29. Judgment of 20 November 2001, Aldona Malgorzata Jany and Others $v$ Staatssecretaris van Justitie, C-268/99, ECLI:EU:C:2001:616

30. Judgment of 21 March 2014, Albanian Constitutional Court, V-14/14, [2014] OJ 50 31. Judgment of 23 March 2016, the Civil Chamber of the High Court, N 94, [2016].

32. Judgment of 29 June 2017, the Civil Chamber of the High Court, N 81, [2017]

33. Judgment of 24 July 2009, Albanian Constitutional Court, V-24/09, [2009] OJ 119 
34. Judgment of 27 April 2015, Judicial Chamber of the High Court, No 1, [2015] OJ 142

35. Judgment of 27 July 2016, Albanian Constitutional Court, V-56/16, [2016] OJ 152

36. Judgment of 27 March 2012, High Court, No 2, [2012] OJ 106

37. Judgment of 27 September 2001, The Queen and Secretary of State for the Home

38. Department ex parte v Wieslaw Gloszczuk et Elzbieta Gloszczuk, C-63/99, ECLI:EU:C:2001:488

39. Judgment of 27 September 2001, The Queen and Secretary of State for the Home Department ex parte $v$ Eleanora Ivanova Kondova, C-235/99, ECLI:EU:C:2001:489

40. Judgment of 27 September 2001, The Queen and Secretary of State for the Home Department ex parte v Julius Barkoci and Marcel Malik, C-257/99, ECLI:EU:C:2001:491

41. Judgment of 27 September 2001, TheQueen and Secretary of State for the Home Department ex parte $v$ Wieslaw Gloszczuk et Elzbieta Gloszczuk, C-63/99, ECLI:EU:C:2001:488

42. Judgment of 29 February 2016, Judicial Chamber of the High Court, No 1, [2016] OJ 93

43. Judgment of 29 June 2017, the Civil Chamber of the High Court, N 81, [2017] 44. Judgment of 30 September 1987, Meryem Demirel v Stadt Schwäbisch Gmünd., C-12/86, ECLI:EU:C:1987:400

45. Judgment of 31 May 2004, Participation of Foreigners in European Parliamentary Elections, K 15/04

46. Judgment of 4 May 1999, Sema Sürül v Bundesanstaltfür Arbeit, C-262/96, ECLI:EU:C:1999:228

47. Judgment of 5 February 2010, Albanian Constitutional Court, V-3/10, [2010] OJ 17

48. Judgment of 8 July 2020, the Civil Chamber of the High Court, N 213, [2020]

49. Korenica, Fisnik., and Doli, Dren. 2012. "The Relationship Between International Treaties and Domestic Law: A View from Albanian Constitutional Law and Practice" Peace International Law Review 24:92-118

50. KühnZdeněk. 2005a. "The Application of European Law in the New Member States: Several (Early) Predictions" German Law Journal 6: 563-582.

51. Kühn. Zdenĕk, 2005b. "European Law in the Empires of Mechanical Jurisprudence: The Judicial Application of European Law in Central European Candidate Countries" Croatian Yearbook of European Law and Policy 1:55-73.

52. KuvendiiRepublikëssëShqipërisë. 20016.

"KuvendiiShqipërisëmiratonreformënnëdrejtësi me 140 vota pro." Accessed 1 may 2021. https://www.parlament.al/News/Index/5833

53. Lang Goldner Iris and Mataija Mislav, 'Application of EU law by Croatian Courts and Relevant Constitutional Provisions' in European Union Law Application by the 
National Courts of the EU Membership Aspirant Countries from South - East Europe, edited by Goran Koevski, et al., 91-98. Skopje: Centre for SEELS 2014. 54. Law 10091/2009, 'For Legal Auditing, Organisation of the Profession of Registered Accounting Expert and Certified Accountant' [2009] OJ 36

55. Law 115/2020, 'For some changes on the Law 8417/1998 Constitution of Albanian Republic as amended' [2020] OJ 153

56. Law 8417/1998, 'Constitution of Albanian Republic' [1998] OJ 28

57. Law 96/2014, 'On the Establishment of a Special Parliamentary Commission on Justice System Reform' [2014] OJ 189

58. Law 97/2013, 'On audio and audio-visual media services in the Republic of Albania [2013] OJ 37/1497

59. Law 96/2016, 'Per. Statusin e Gjyqtarevedhe Prokurorëve në Republikën e Shqipërisë' [2016] OJ 208

60. Law 98/2016, 'The Organisation of the Judicial Power in the Republic of Albania' [2016] OJ 209

61. Marko, Joseph., and Wilhelm, Judith. 2002. "Stabilisation and Association Agreements" in, Handbook on European Enlargement: a Commentary on the Enlargement Process, edited by Andrea Ott and Kirstyn Inglis, 165-174.The Hague:T.M.C. Asser Press.

62. Mataija, Mislav. 2015. "The Unfulfilled Potential of Stabilisation and Association Agreements before SEE Courts" in Judicial Application of International Law in Southeast Europe, edited by Siniša Rodin and Tamara Perišin, 11-30. SpringerVerlag Berlin Heidelberg

63. Meškić Zlatan and Samardžić Darko, 'The Application of EU Law in Bosnia and Herzegovina' in European Union Law Application by the National Courts of the EU Membership Aspirant Countries from South - East Europe, edited by Goran Koevski, et al., 61-70. Skopje: Centre for SEELS 2014.

64. Omari Luan and Anastasi Aurela. 2010. E Drejta Kushtetuese Tiranë: ABC

65. PGDP (Parliamentary Group of Democratic Party). 2016. "Opinion of the Experts of Opposition in Connection to the Constitutional Amendments." Opinion No 2. Accessed 20 June 2021 https://www.euralius.eu/images/Justice-Reform/Opinionof-the-experts-of-opposition-in-connection-to-the-Constitutionalamendments.pdf point III-2(1)

66. Regulation (EEC, Euratom) 1182/71 of the Council of 3 June 1971 determining the rules applicable to periods, dates, and time limits [1971] OJ L 124/1

67. Regulation (EU) 1215/2012 of the European Parliament and of the Council of 12 December 2012 on jurisdiction and the recognition and enforcement of judgments in civil and commercial matters [2012] OJ L351/1

68. School of Magistrates. 2021. "Academic Program for the formation of the School of Magistrates." Accessed 1 July 2021. https://magjistratura.edu.al/\#115 
69. Stabilization and Association Agreement between the European Communities and their Member States, of the one part, and the Republic of Albania, of the other part - Protocols - Declarations [2009] OJ L 107

70. Vendimi 96/2014 'Për Krijimin e Komisionittë Posaçëm Parlamentar për Reformën në Sistemin e Drejtësisë' [2014] FZ 189.

71. Venice Commission. 2016b. 'Amicus Curiae - Brief for the Constitutional Court on the Law on the Transitional Re-evaluation of Judges and Prosecutors (The Vetting Process)' (Opinion No. 868/2016) CDL-AD(2016)036

72. Venice Commission. 2015. "Consolidated version of the Constitution of the Republic of Albania Integrating the Draft Constitutional Amendments." Opinion no. 824 / 2015. CDL-REF(2016)008.

73. Venice Commission. 2016a. ' Final Opinion on the Revised Draft Constitutional Amendments on the Judiciary (of 15 January 2016) of Albania' Opinion No. 824 / 2015. CDL-AD(2016)009

74. Vukadinović, D Radovan., et al. "Application of EU Law by Serbian Courts PreAccession Issues" in European Union Law Application by the National Courts of the EU Membership Aspirant Countries from South - East Europe, edited by Goran Koevski, et al., 141-158. Skopje: Centre for SEELS 2014.

75. Weiler, HHJ. 1991. "The transformation of Europe" Yale Law Journal, 100:24032483

76. Zymberi, Gentian., and Sali, Semir. 2015. "The Place an Application of International Law in Albanian Legal System" in Judicial Application of International Law in Southeast Europe, edited by Siniša Rodin and Tamara Perišin, 81-108. Springer-Verlag Berlin Heidelberg. 